\title{
HEAT TREATMENT OF RAILS
}

\section{TOPLOTNA OBDELAVA TIRNIC}

\author{
Milan Hnizdil, Petr Kotrbacek \\ Brno University of Technology, Faculty of Mechanical Engineering, Heat transfer and fluid flow laboratory, \\ Technicka 2896/2, 616 69, Brno, Czech Republic \\ hnizdil@fme.vutbr.cz \\ Prejem rokopisa - received: 2015-12-23; sprejem za objavo - accepted for publication: 2016-03-31
}

doi:10.17222/mit.2015.357

\begin{abstract}
Heat treatment is increasingly used in the heavy industry. The main advantage of this method is the achievement of the required material and mechanical properties. Heat treatment allows for a manufacturing process, which can improve product performance by increasing the steel strength, hardness and other desirable characteristics. The microstructure, grain size and chemical composition of steel affect its overall mechanical behavior. Heat treatment is an efficient way to manipulate the properties of a steel product by controlling the cooling rate. It can be expressed using the heat-transfer coefficient (HTC). The controllability of the cooling process is very important. Mist and water nozzles may provide good controllability of the HTC. An experimental stand was designed and built. The stand consists of a movable trolley with a test sample, which moves under a spray at a given velocity. Sensors record the temperature history of the tested material. This experimental stand enables simulations of a variety of cooling regimes and evaluations of the final structures of tested samples. The same experimental stand is also used for designing cooling sections in order to determine the required heat-treatment procedures and the final structures. This paper describes a cooling-section design procedure for obtaining the required structure and mechanical properties of rails.

Keywords: heat transfer, heat treatment, cooling, heat-transfer coefficient, spray cooling
\end{abstract}

Uporaba toplotne obdelave se v težki industriji povečuje. Glavna prednost te metode je, da se doseže zahtevane mehanske lastnosti materiala. Toplotna obdelava omogoča postopke izdelave, ki lahko izboljšajo lastnosti proizvodov s tem, da povečajo trdnost jekla, trdoto in druge zaželjene značilnosti. Mikrostruktura, velikost zrn in kemijska sestava jekla vplivajo na mehanske lastnosti. Toplotna obdelava je učinkovita pot za vplivanje na lastnosti jeklenega proizvoda s kontroliranjem hitrosti ohlajanja. Lahko se jo izrazi z uporabo koeficienta prenosa toplote. Možnost kontrole postopka ohlajanja je zelo pomembna. Obvladanje procesa ohlajanja je zelo pomembno. Vodna para in vodne šobe omogočajo dobro kontrolo koeficienta prenosa toplote (angl. HTC). Načrtovano in postavljeno je bilo eksperimentalno stojalo. Stojalo sestoji iz vozička z vzorcem, ki se pomika pod šobe z dano hitrostjo. Senzorji beležijo temperaturno zgodovino vzorca. Eksperimentalno stojalo omogoča simulacijo različnih režimov ohlajanja in oceno končne mikrostrukture preizkušenega vzorca. Isto stojalo je uporabno tudi kot orodje pri načrtovanju hladilnih odsekov za določanje postopka toplotne obdelave in končne mikrostrukture. Članek opisuje postopek načrtovanja odseka za izvajanje hlajenja, za zagotavljanje željene mikrostrukture in mehanskih lastnosti železniških tirnic.

Ključne besede: prenos toplote, toplotna obdelava, ohlajanje, koeficient prenosa toplote, ohlajanje s pršenjem

\section{INTRODUCTION}

Heat treatment of rolled materials by hot rolling plants has become frequent. Alloying elements are typically used to improve material properties. Heat treatment is a different approach applied to achieve the required material properties using fewer alloys in the steel. Heat treatment enables the manufacture of modern steels with a higher ratio of yield strength and elongation. The controllability of the cooling process is the most important aspect for achieving the required mechanical properties. An appropriate cooling intensity and its duration are chosen with respect to the continuous cooling transformation diagram (CCT) for the selected material. Numerical simulation of the cooling follows. One task is to determine the boundary condition (HTC - heat transfer coefficient) for the simulation because various parameters such as nozzle type, spray distance, water impingement density, nozzle position, nozzle overlap, movement velocity and scales have significant influences on the cooling intensity. ${ }^{1-3}$ Additionally, accurate thermo-physical material properties are needed for simu- lations. ${ }^{4}$ The Heat Transfer and Fluid Flow Laboratory developed a methodology for predicting the temperature field of heat-treated rails. This methodology is described in this article.

\section{DESIGN STRATEGY FOR THE COOLING SECTION}

Three different types of experiments were done to predict the required cooling regime defined by the CCT diagram. A special hardening-capacity test bench (Figure 1) was developed to find the limits of a quenched rail. The test bench consists of a heater, a trolley with a tested sample, a water nozzle holder and a pneumatically driven deflector.

Each test starts with heating a rail-head sample to the initial temperature. This temperature is held for more than $10 \mathrm{~min}$ to attain the austenite structure of the entire body. The sample is protected with an inert atmosphere in the furnace to prevent the development of scales. Next, the sample is moved from the heater to a position 


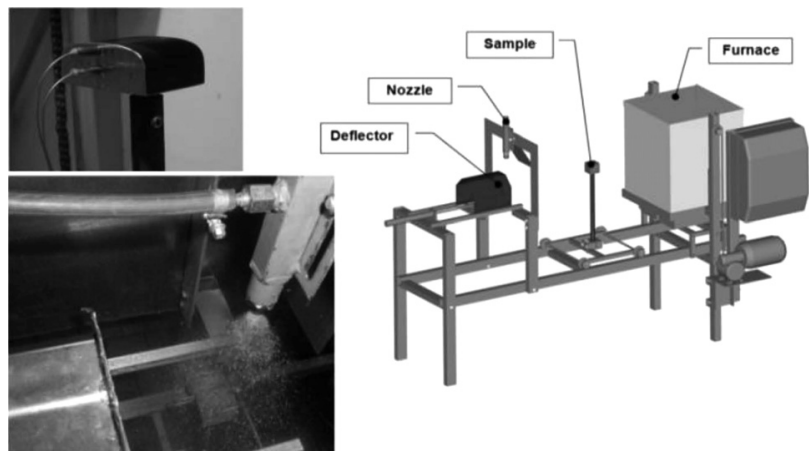

Figure 1: Hardening-capacity test bench

Slika 1: Preizkušanje zmogljivosti utrjevanja

under the nozzle. The pneumatically driven deflector, positioned between the nozzle and the sample, is moved and the water sprays the top of the rail head. Each sample is equipped with thermocouples under the surface to detect the temperature gradient in the material. The material hardness and its structure are observed. The hardness values of the original (base) material and the heat-treated material are compared because the heattreatment process is dependent on the quality of the steel-making process (chemical composition, enclosures, casting speed, etc.). ${ }^{5-8}$

If these tests are sufficient, heat-transfer tests are then performed. A special testing bench called a linear stand (Figure 2) was developed by the Heat Transfer and Fluid Flow Laboratory. This bench is a six-meter long girder with a trolley which can move the tested rail sample, plate, etc., through the cooling section. A $25 \mathrm{~mm}$ thick, flat austenitic steel plate is used for the heat-transfer tests. It is embedded with four thermocouples positioned $0.5 \mathrm{~mm}$ under the sprayed surface. This plate is moved through the spray-cooling system ( $2 \mathrm{~m}$ long) in two directions, forward and backward.

The dependences of the heat-transfer coefficient on the surface temperature are evaluated for various cooling parameters (spray distance, type of nozzle, water impingement density, etc.). The obtained boundary conditions are used for simulations to predict the temperature

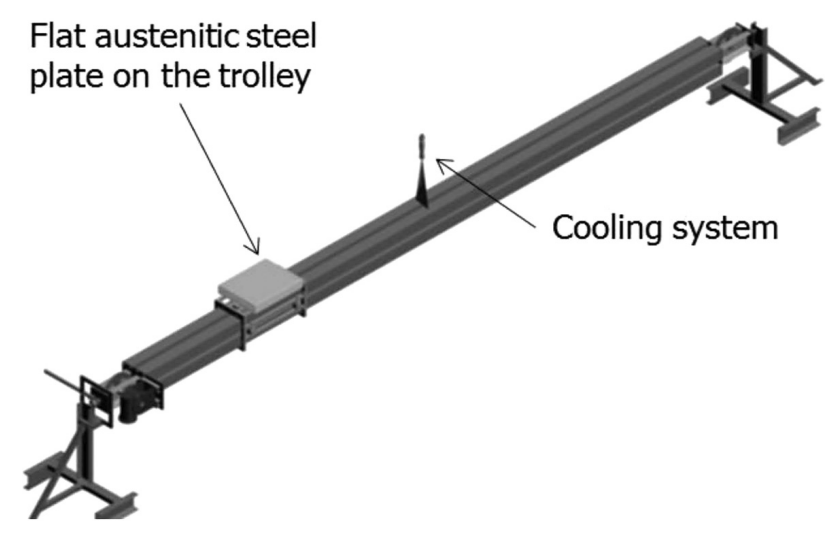

Figure 2: Linear-stand scheme

Slika 2: Shema linearnega stojala field in the rail head. The shape of the rail also has a significant influence on the cooling intensity. Therefore, an authentically shaped austenitic steel sample is made and embedded with several thermocouples, positioned 2 $\mathrm{mm}$ under the rail surface. The length of this sample is around $300 \mathrm{~mm}$. Simulations of the rail cooling are compared with the temperatures measured during the austenitic rail cooling. The boundary conditions obtained from the flat austenitic steel plate are adjusted and the model is verified with measurements. The last step is the verification including a full-scale, carbon-rail sample. A sample is fixed on the trolley (the linear stand) and moved through the cooling section. The measured and simulated temperatures are compared and the cooling model is verified. Finally, the hardness is measured again. This is the most important result that shows if the cooling regime works optimally.

\section{RESULTS}

The cooling strategy was described in Section 2. The experimental steps began with the study of CCT diagrams. Material R260 was chosen for the heat-treatment tests. The hardness-capacity tests were performed first to find the limit of the quenched material and to choose the appropriate nozzle size with respect to the required cooling regime. All the tested samples were embedded with thermocouples to verify the cooling regime. These samples were sawed after quenching and hardness was measured along the center line of the rail head (from the top of the surface down to the center - the red line). An example of the cooling regime (for a successful test) is shown in Figure 3.

The measured hardness for this sample was around 400 HV0.3 (Figure 4). The required fine pearlite structure was found using a microstructure analysis (Figure 5).

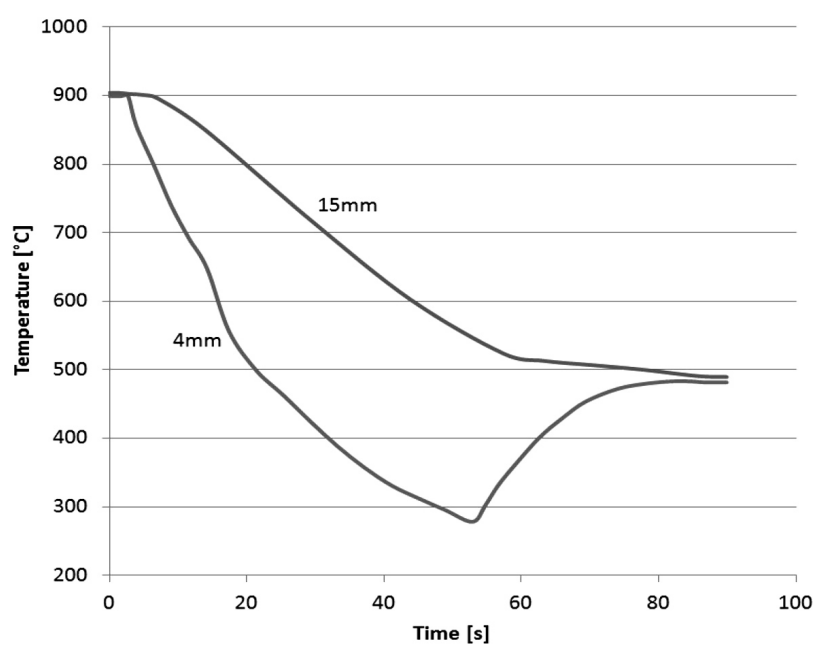

Figure 3: Temperature record for the rail head during a successful static-hardness-capacity test

Slika 3: Zapis temperature glave tirnice med uspešnim preizkusom zmogljivosti trdote 


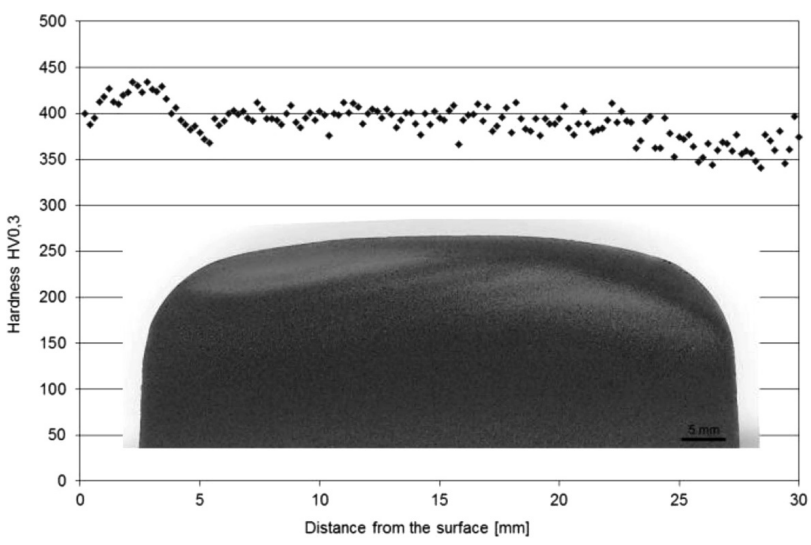

Figure 4: Measured hardness of the rail head after the static-hardness-capacity test

Slika 4: Izmerjena trdota $v$ glavi tirnice med statičnim preizkusom trdote

An appropriate choice of the nozzle and the verification of the cooling regime using the CCT diagram were confirmed with a static-hardening-capacity test. The next step was to find the cooling parameters for the moving samples (transient boundary conditions). The linear stand was used for these tests. A $25 \mathrm{~mm}$ thick, flat austenitic steel plate was used and several parameters such as water pressure, spray distance, spray angle and
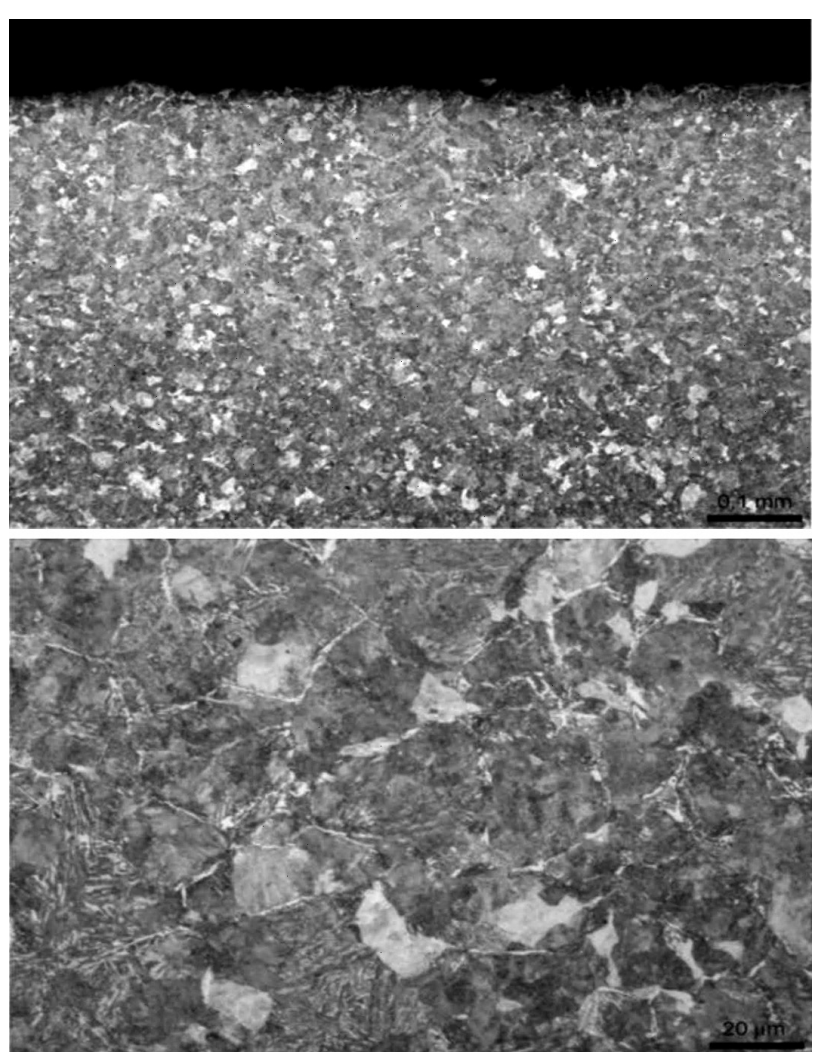

Figure 5: Microstructure - close to the sprayed surface - center of the rail-head surface

Slika 5: Mikrostruktura - blizu poškropljene površine - sredina površine glave tirnice

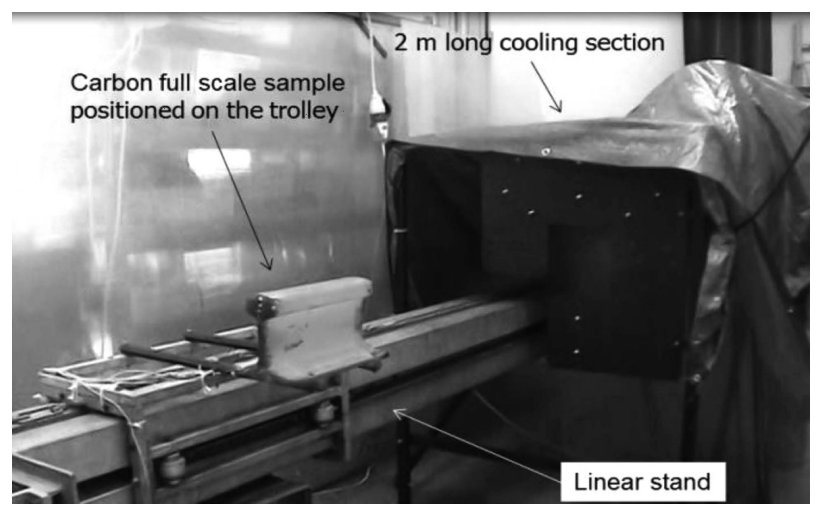

Figure 6: Full-scale carbon sample heated to the initial temperature before entering the cooling section

Slika 6: Realen vzorec ogret do začetne temperature pred vstopom v področje ohlajanja

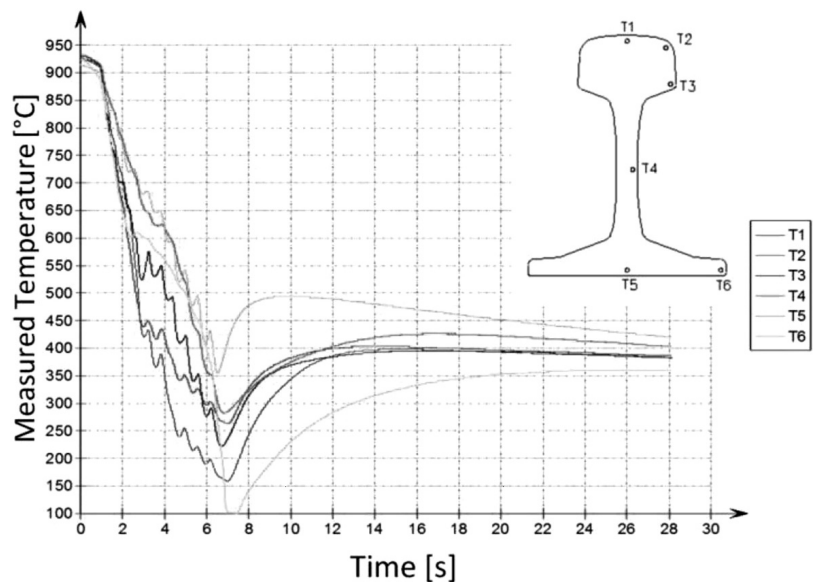

Figure 7: Temperature record for the heat-treated full-scale sample Slika 7: Temperatura zabeležena na toplotno obdelanem realnem vzorcu

movement velocity were tested. The boundary conditions obtained from the experiment were used to simulate the cooling regime for a real moving rail. A full-scale rail sample (material R260) was built and embedded with six thermocouples positioned $2 \mathrm{~mm}$ under the surface (Figure 6).

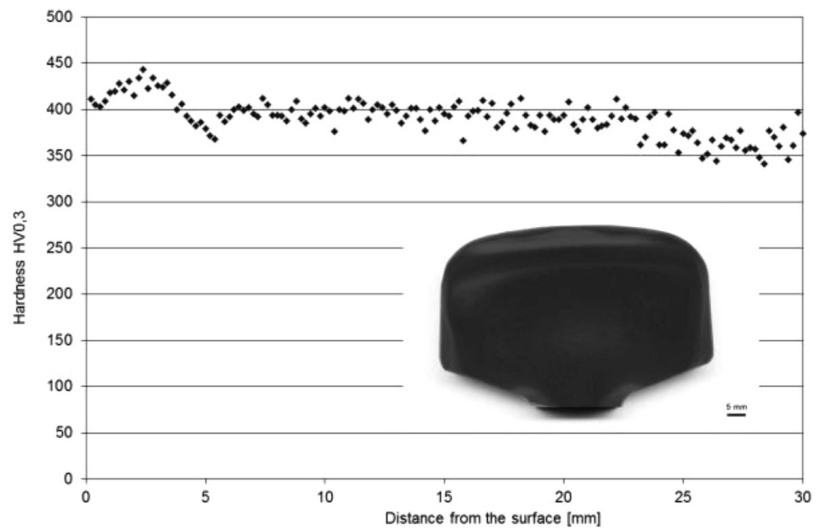

Figure 8: Measured hardness at the center line of the rail head Slika 8: Trdota izmerjena na sredini glave tirnice 
The first full-scale test showed that the rail shape has a significant influence on the cooling intensity, so additional experiments with a full-scale austenitic sample and temperature-field prediction-model tuning were necessary to obtain the required material structure. Finally, a full-scale, carbon-rail sample was made and it too was embedded with thermocouples. Simulated temperatures were compared to measured temperatures and the model was verified. An example of the cooling regime of a successful full-scale test is shown in Figure 7.

The measured hardness of this sample was around 400 HV0.3 (Figure 8). This corresponded to the results from the static-hardening-capacity test.

\section{CONCLUSION}

The goal of this article was to illustrate a verified methodology for rail heat treatment. The first step was to compute a CCT diagram and determine the settings for the optimum cooling regime to achieve the required material structure. The accuracy of the CCT diagram was verified with a hardening-capacity test (Jominy test). The next step was to measure the dependence of the heattransfer coefficient on the surface temperature using a flat austenitic steel plate with thermal sensors. Various cooling parameters were tested: water pressure, spray distance, spray angle, movement velocity and others. These boundary conditions were used to predict the temperature-field evolution in the rail. It was found that the rail shape has a significant influence on the cooling intensity. A full-scale austenitic steel rail sample $(300 \mathrm{~mm}$ long) was made and the cooling model was tuned using simulation data and the temperatures measured during the experiments with a full-scale sample. The final design of the cooling section was made and the cooling model was verified by measuring an authentic full-scale carbon sample in the laboratory. The final hardness of the heat-treated rail sample was measured and compared with the data obtained during the hardening-capacity

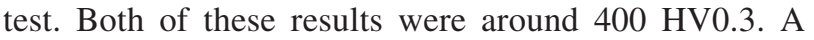
fine perlite structure was found along the center line of the heat-treated rail-head sample.

\section{Acknowledgement}

The research leading to these results received funding from the MEYS under the National Sustainability Programme I (Project LO1202).

\section{REFERENCES}

${ }^{1}$ M. Chabicovsky, M. Raudensky, Experimental Investigation of a Heat Transfer Coefficient, Mater. Tehnol., 47 (2013) 3, 395-398

${ }^{2}$ M. Raudensky, M. Chabicovsky, J. Hrabovsky, Impact of Oxide Scale on Heat Treatment of Steels, Proc. of the $23^{\text {rd }}$ International Conference on Metallurgy and Materials, Brno, 2014, 553-558

${ }^{3}$ M. Chabicovsky, M. Hnizdil, A. A. Tseng, M. Raudensky, Effects of Oxide Layer on Leidenfrost Temperature during Spray Cooling of Steel at High Temperatures, International Journal of Heat and Mass Transfer, 88 (2015), 236-246, doi:10.1016/j.ijheatmasstransfer. 2015.04.067

${ }^{4}$ T. Mauder, C. Sandera, J. Stetina, Optimal Control Algorithm for Continuous Casting Process by Using Fuzzy Logic, Steel Research International, 86 (2015) 7, 785-798, doi:10.1002/srin.201400213

${ }^{5}$ K. Gryc, K. Stransky, K. Michalek, A Study of the High-Temperature Interaction between Synthetic Slags and Steel, Mater. Tehnol., 46 (2012) 4, 403-406

${ }^{6}$ K. R. Santanu, Surface Quality of Steel Products, Role of Chemistry, Steelmaking \& Continuous Casting, New Delhi 2006

${ }^{7}$ L. Klimes, J. Stetina, L. Parilak, P. Bucek, Influence of Chemical Composition of Cast Steel on Temperature Field of Continuously Cast Billets, Proc. of the $21^{\text {st }}$ International Conference on Metallurgy and Materials, Brno, 2012, 135-141

${ }^{8}$ T. Mauder, J. Stetina, Improvement of the Casting of Special Steel with a Wide Solid-Liquid Interface, Mater. Tehnol., 50 (2016) 1, 3-6, doi:10.17222/mit.2014.122 